\title{
A landscape of lies: Soviet maps in Estonia
}

\author{
Marti Veldi ${ }^{1,1}$ and Simon Bell ${ }^{1}$ \\ ${ }^{1}$ Estonian University of Life Sciences, Chair of Landscape Architecture, Tartu, Estonia
}

\begin{abstract}
Maps have long been used as ways of understanding the land as a means of defining borders, land ownership, resources, estimating tax-gathering potential and for defensive purposes. Many of the national mapping agencies originated as arms of the military. When a new regime takes over a country it may decide to prepare its own set of maps - not least for defensive purposes - and to restrict who has access to these maps. When the Soviet Union occupied the Baltic States in 1945 - and these became front-line areas during the Cold War, with large areas devoted to military installations and border zones - a whole new set of maps were created. We took a sample of maps of Estonia from the inter-war years and from the period of political and military occupation from 1945-1991. The Soviet army maps became freely available in the post-Soviet period and studying them and comparing them with the older maps reveals the way the land was perceived. Military maps were produced using different projections and scales, especially regarding the topography and other features relevant for military operations. The maps included deliberate mistakes and if publicly available they contained many blank spaces to hide sensitive areas and to pretend they did not exist. We also found that maps played a key role in planning future landscapes - kolkhoz maps showed how Estonia was foreseen as a complete planned system covering the whole country outside urban areas.
\end{abstract}

\section{Introduction}

Maps have long been used by different regimes at different administrative levels, ranging from empires to nation states to large landowners or specific organisations such as military or tax agencies as ways of understanding the land as a means of defining borders, land ownership, giving land to colonists, to record natural resources, agricultural potential, for estimating tax-gathering potential and for defensive purposes.

Early maps were inaccurate as a result of a lack of a coordinate system and means of relating specific points to an underlying framework. Once the concept of Cartesian coordinates was established in the $17^{\text {th }}$ century by René Descartes (or Cartesius, his Latin name) it was possible to produce accurate maps whose potential was seen by the navies or armies of various countries or empires in those times. Many of the national mapping agencies originated as arms of the military. When a new regime takes over a country it may decide to prepare its own set of maps - not least for defensive purposes -

\footnotetext{
${ }^{1}$ Corresponding author: martti.veldi@emu.ee
} 
and to restrict who has access to these maps. When the Soviet Union occupied the Baltic States in 1945 - and these became front-line areas during the Cold War, with large areas devoted to military installations and border zones - a whole new set of maps were created.

Besides being a graphical description of the surrounding environment, maps also convey valuable economic and strategic military information, which in the case of armed conflict can give a considerable advantage over resources and means of transportation as well as tactical advantages for fighting or defence. Topographic mapping for military purposes have often been the historic bases of national cartographies and their mode or representation, use of scales and symbology still reflect this in many instances.

Secrecy and deceit around maps and cartography is as old as the history of mapping itself. Starting at least from the times of the great explorations in the $15^{\text {th }}-16^{\text {th }}$ centuries, maps have been seen as secret keys to unimaginable treasures, and thus sources which have to be guarded from thieves and unwanted eyes [1].

The new age of classified maps dawned with the development of methods of recording detailed topography, which was essential knowledge for military. Already in 1798, the Russian czar Paul I signed a law which required that all geographical maps had to be presented to the Geography Department of the Senate for inspection and all topographic maps of potential military importance had to be handed over to the Cartographic Depot of the General Staff. For example, according to the law, it was forbidden to sell the printed pages of the Livonian Atlas (which includes much of Latvian and the southern section of Estonia) compiled by L. A. Mellin between 1781-1810, and all the maps from his atlas were confiscated, both from the shops and from civilian owners who had bought them [2].

In the Soviet Union, all topographic maps starting from the scale 1:1 million $(1 \mathrm{~cm}=$ $10 \mathrm{~km}$ in nature) and larger were declared secret. Thematic and special maps based on these topographic maps, aerial photos, coordinates of geodetic points, and historic topographic maps were also considered forbidden [1], and not allowed to be used for civil purposes.

This control over how people were able to understand their land and landscape was, in Soviet times therefore an important aspect of establishing and maintaining state control; it was also linked with all the modernisation projects which went on in those days - in the relationship of maps and plans for collectivisation, for example, and how sections of detailed plans which included drainage schemes, could be implemented when accurate local topographical information was needed. In order to track down some of the cartographic lies in Soviet Estonia in more detail, we compared inter-war topographic maps from the 1930s, and topographic maps from 2010s with Soviet topographic maps of the unique Pulkovo '42 (known as 042-series) and Pulkovo '63 (c63-series) coordinate systems and also to look at an interesting way in the way some maps told a story that never happened.

The example cases include: 1) the Soviet Union military airport in Ämari, NorthEstonia 2) the militarised island of Naissaar on the northern coast of Estonia 3) The idealistic mapping of how the whole country's collectivisation system should develop, a vision compiled in 1960 with a prognosis for $1980^{2}$.

\section{Levels of secrecy in Soviet mapping}

The centralisation of cartography achieved its peak in the Soviet Union, where mapping was directly organised and controlled by the Council of Ministers. During Stalinist rule, 
even owning a topographic map could bring forth very strong allegations of espionage. Losing a topographic map could mean up to 8 years' imprisonment [1].

According to the directive of the Soviet Union's Council of Ministers issued in 1966, there were four levels of secrecy for maps in the Soviet Union:

1) Very secret - so secret, that it was even forbidden to mention them in the directive.

2) Secret - all topographic maps of whatever projection or reference system larger than 1: 1000000 scale.

3) Maps for professional purposes - special maps, such as geology, soil, agriculture, land use etc. in the scale of 1:1000 000 to 1:2 500000 . It was forbidden to depict objects of military, industry, or transport function.

4) Public maps - mostly geographical maps for educational purposes, derived from the basic map of the Soviet Union in the scale of 1:2500 000. It was allowed to draw maps of an extent up to 25 ha using a local coordinate system. With certain restrictions, students could also use professional agricultural and forestry maps if they substituted the real place names with fake ones (!) [1].

\section{Conflicting and confusing reference systems}

In 1946 the Soviet Union started to use, as the basis for topographic maps, the coordinate system known as Pulkovo '42. In 1963, another parallel coordinate system of Pulkovo '63 was introduced. Although this was based on Pulkovo '42, the spatial reference system of Pulkovo ' 63 was considerably altered in terms of the coordinates of base points, and the number of coordinate system zones and map frames. The coordinate grid on the maps was without numerical values. It was forbidden to store or use the same maps based on the different coordinate systems in one institution. Even the term "coordinate system of 1963" was declared secret. The changes in the reference system and maps themselves were also classified. It was thought that the confusion around coordinate systems would help to protect the Soviet Union against enemy missiles, which needed precise coordinates for targeting. The instructions for classifying topographic maps were changed to become ever stricter several times, and it was only in 1987, when the use of two confusing and conflicting coordinate systems was ended [1].

\section{Sources}

The National Archives of Estonia boast almost 150000 historic maps [3], of which more than 50000 have been digitised, and made accessible to the public over the Internet. The Estonian Land Board also provides an elaborate platform of contemporary and historic maps, both online and through WMS-service [4]. This kind of general dissemination of potentially strategic information would have been completely unimaginable in the totalitarian Soviet Union.

We compared maps from three different periods for two of the case studies: Ämari military airfield, Harju County and the military island of Naissaar.

1) Topographic map (1935-1939) of the Estonian Republic, in the scale of 1: 50000 is the best map characterising the inter-war period, composed and used by the military [4]

2) Topographic maps (42o series, c63 series) of Soviet Estonia at the scale of 1: 25 000. Military topographic maps, forbidden for civilians [4]

3) Estonian Basic map (2010s) digital version, in the scale of 1: 10000 (the most arciurate man on the rentemnnrary land ice) 「41 
The third case study is more of an examination of how the ideological self-delusion could also be reflected in maps - in this case the entire country and its complete breakdown into the collective agriculture system, with a grandiose scheme for its development into the future - which turned out to be well-beyond the lifespan of the Soviet system. For this we just examine a single map $^{2}$ comprising two sets of overlaid information: a schematic map of collectivisation in Soviet Estonia in 1960 with the prognosis of changes for 1980 (which never happened).

\section{Ämari military airfield, Harju County}

On the $15^{\text {th }}$ of May 1940, the (forced) military pact between the Republic of Estonia and Soviet Union was signed. The pact consisted of 23 articles, and a supplement of 45 points.

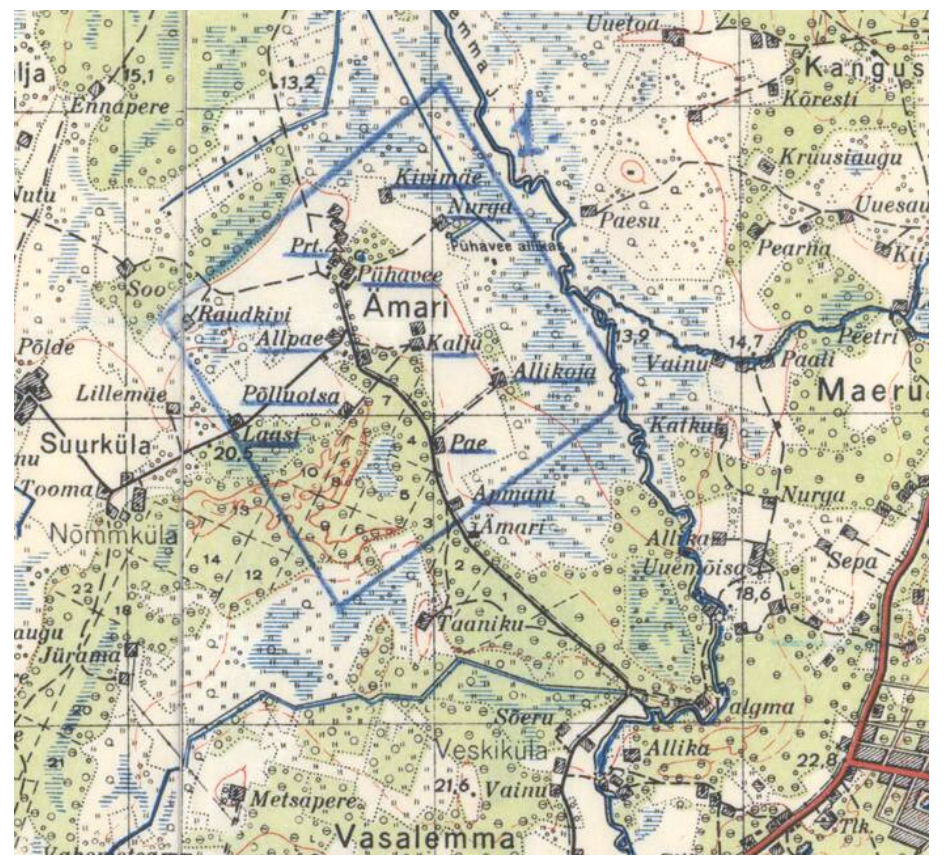

Fig. 1. The position of the Ämari airfield hand-drawn over the 1936 topographic map in 1940 by an unknown Soviet military officer. (Source: $\left[{ }^{3}\right]$ ).

One of the points in the supplement included a decision to establish a military airfield on the lands of Ämari manor in Harju County, North Estonia. The Red Army demanded 240 hectares of land to be handed over by the $1^{\text {st }}$ of June 1940, and the Soviet military airport was built in Ämari in 1940-1941. One of the first outlines of the land for the airfield has been hand- drawn on the military topographic map of 1936 in 1940 by an unknown military officer (Fig. 1.) stored at the Estonian National Archives $^{3}$.

\footnotetext{
${ }^{2}$ RPI EESTI PÕLLUMAJANDUSPROJEKT [RPI Estonian Agricultural Project], 1962. Eesti NSV skeem maakasutuse piiridega seisuga 1960. aasta ja perspektiiviga 1980. Aastaks [Soviet Estonia's schematic map of land use borders of 1960 with the perspective of 1980]. National Archives of Estonia, EAA.5311.58.218 leht 1.

3 Harjumaal Padise vallas Padisel ja Ämaris NSVL sõjaväele kasutada antavate maa-alade paigutusplaan (VV otsus 26.juuni 1940) (1940) [Situation plan of land in Padise, Harju County, Padise and Ämari municipalities to be given to Soviet Union Army (decision 26. June 1940)]. National Archives of Estonia, ERA.31.2.1009 leht 21.
} 


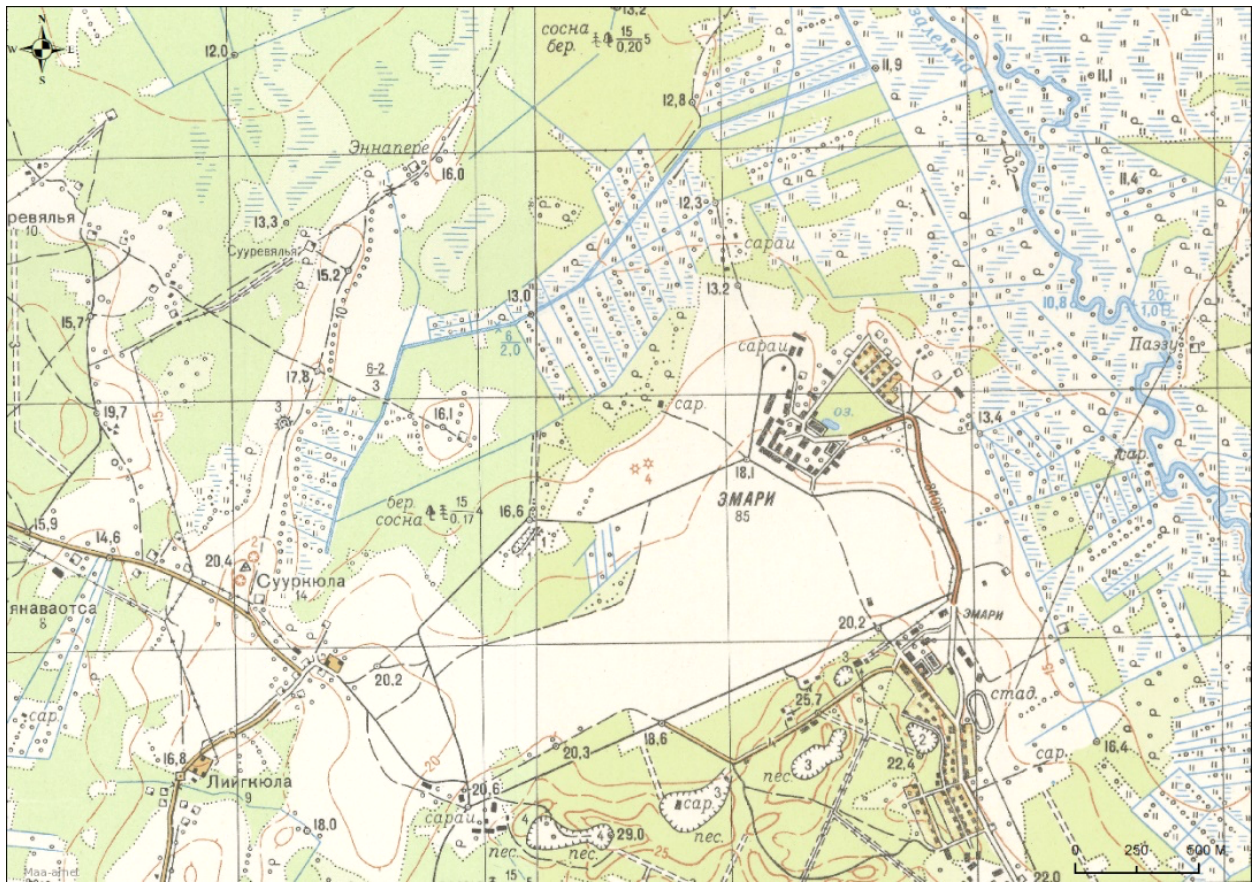

Fig. 2. The area of Suurkjula airfield depicted as agricultural land on the c63-series map from 1976. The original map was produced at 1: 25000 scale. (Source: Estonian Land Board).

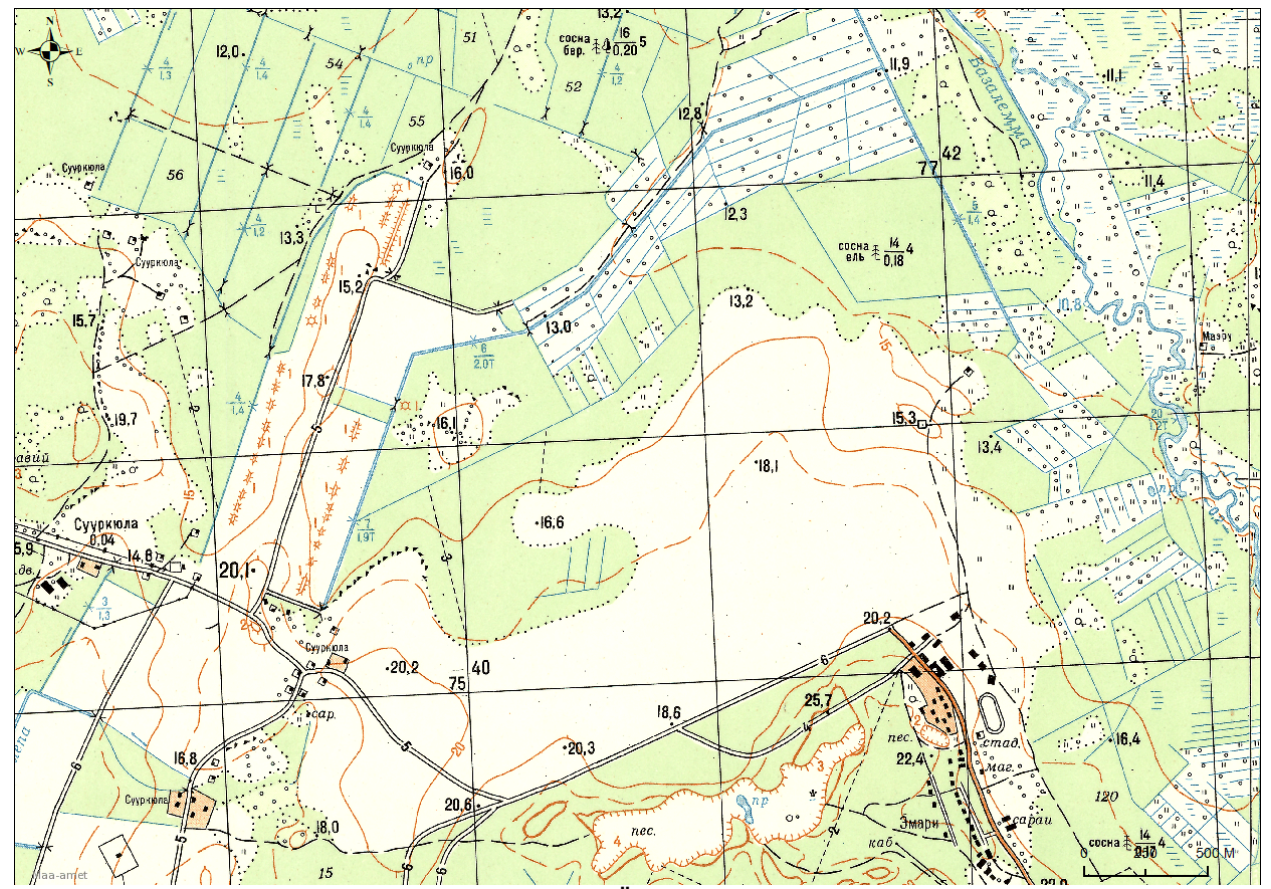

Fig. 3. The 042-series map from 1987, when Ämari served as the Soviet Union Baltic Sea navy airfield conveys even less information - and the location of the name has been relocated since the military complex has been removed. The original map was produced at 1: 25000 scale. (Source: Estonian Land Board). 
The construction of the military airfield in Ämari was continued in 1945, after the end of the German occupation of Estonia, 1941-1944. During the Soviet occupation (19441991 ) the airfield was referred to as Suurküla (literally "big village") airfield (in Russian: аэродром Сууркюль, [aerodrom Suurkjul]); in the Russian army vernacular language, it was also known as Sirgulii. This is also a good example how local Estonian place names were bent in Russian.

As an important military site, the Suurküla airfield never existed on any maps. Both the topographic maps of 042-series (Fig. 2.) and c63-series (Fig. 3.) indicate that the area was used as agricultural land. There is a big blank space there which nevertheless looks somewhat like an outline for an airfield! A lot of buildings are shown which could have a military purpose if one knew what one was looking for!

Extensive expansion of the airfield started in 1956, when the $2450 \mathrm{~m}$ long runway was constructed. In the 1980s Ämari served as the base for the bomber squadrons of the Soviet Union Baltic Sea Fleet. After the collapse of the Soviet Union the airfield was still in the possession of the Russian Federation in until 1994. Since 1996 the airfield has been the main training military airfield of the Estonian air forces (Fig. 4.), and since 2014 it has hosted a NATO air guard unit [5]. On contemporary maps the airfield layout and runways can clearly be seen and of course it is visible on GoogleEarth too!

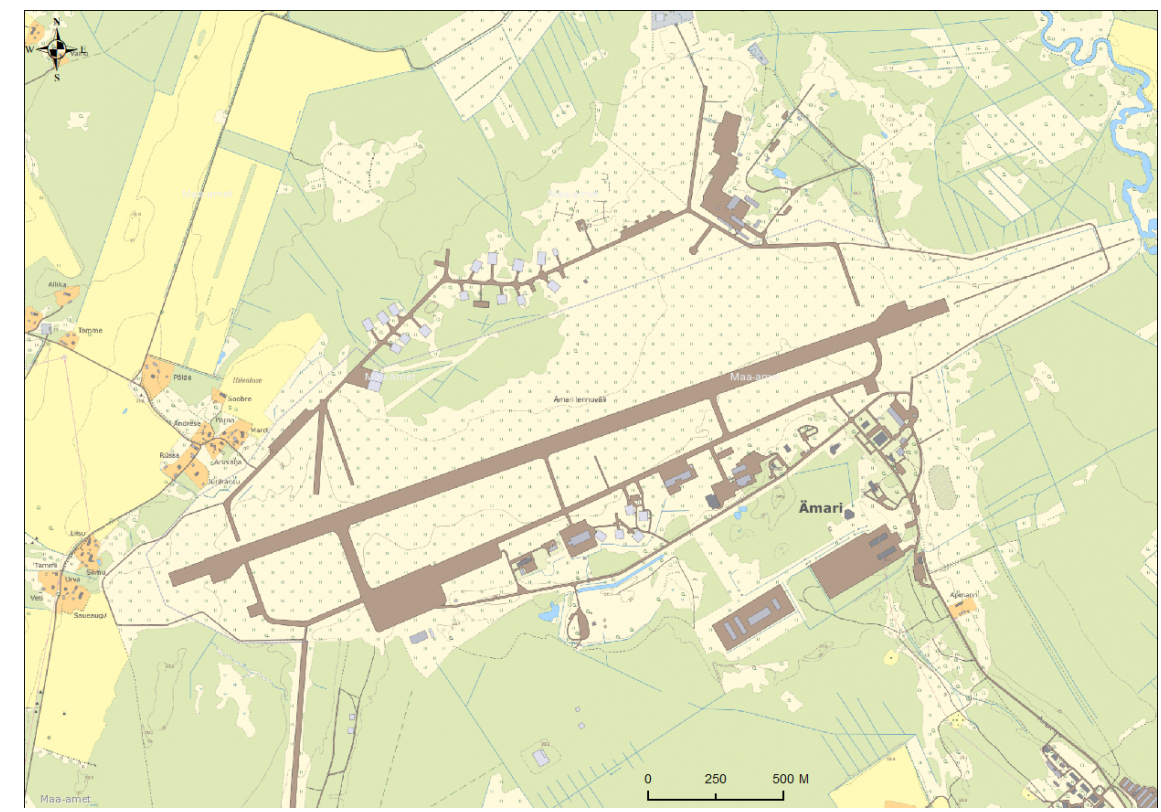

Fig. 4. Ämari airfield in 2018. It is clear how much detail is now allowed on such maps (extracted from the 1: 20000 base map). (Source: Estonian Land Board).

\section{Military island of Naissaar}

The island of Naissaar (Nargen) is situated in the Gulf of Finland, some $15 \mathrm{~km}$ northwest from Tallinn. Historically, due to the location of the island, it has been the focus of military activity since at least 1912, when the island became part of the marine and coastal defence system known as Peter the Great's Sea Defence (Морская крепость Императора Петра Великого [Morskaya krepost' Imperatora Petra Velikogo]) established by czarist Russia between 1912 and 1918. The whole island was militarised: harbours, a railway, and coastal defence batteries were built. The local 
inhabitants were resettled elsewhere and compensated for the loss of their income from fishing and seal hunting [6]. Parts of the coastal batteries from the czarist times still remain today and are protected cultural heritage.
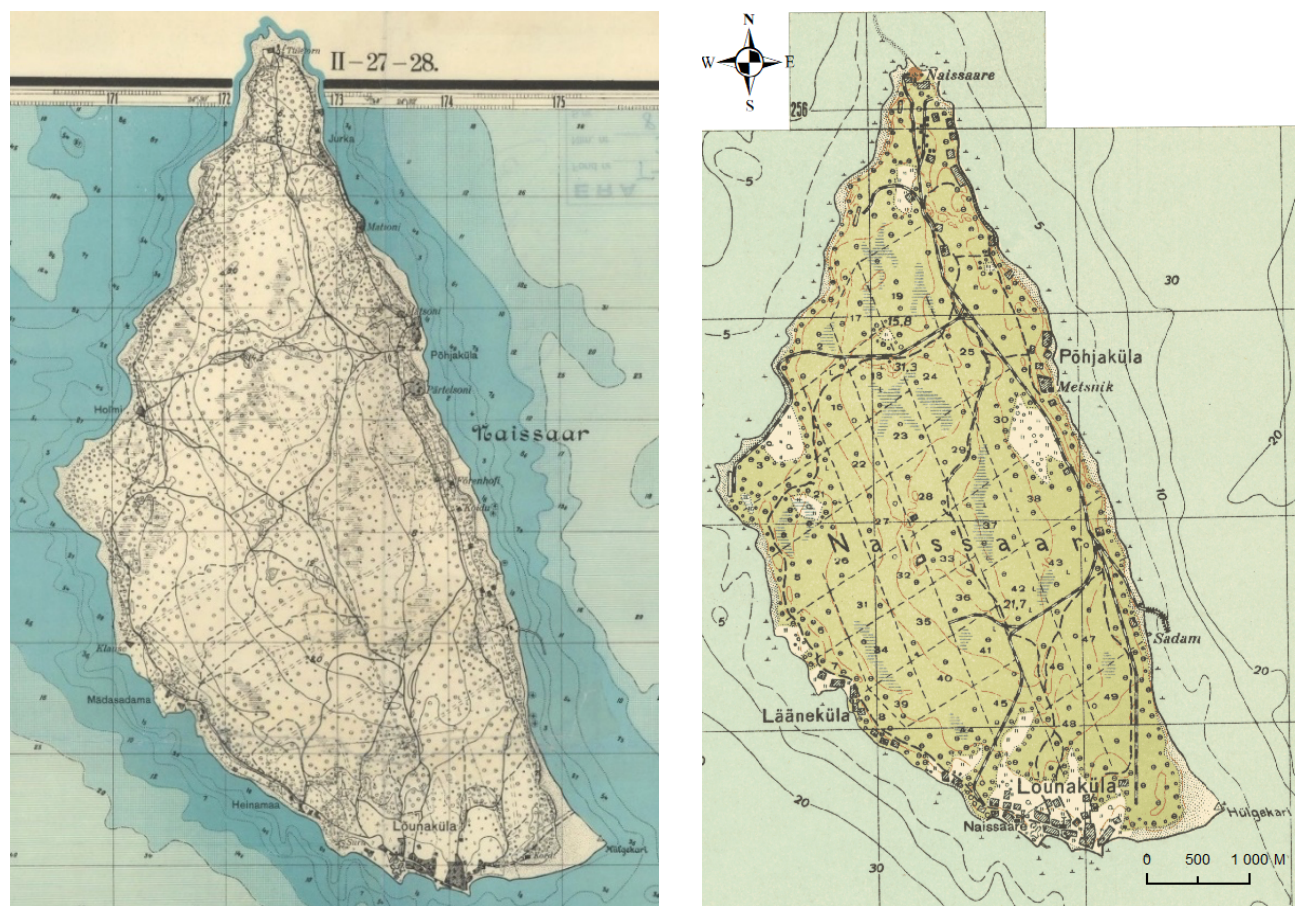

Fig. 5. The island of Naissaar in 1925 and 1936. The island was mostly forested at that time. Map originals at 1:25000 and 1:50 000 scale. (Source: Estonian Land Board).

During the inter-war period, Naissaar (Fig. 5.) hosted the $4^{\text {th }}$ and $5^{\text {th }}$ Estonian coastal batteries with 160 men, railway and storage houses for military purposes [7]. The former inhabitants (mostly Swedes) were allowed to return, and in 1939 there were 404 people permanently living on the island.

At the beginning of the 1950s the Soviet Union military-industrial complex started to build a factory complex for making anti-ship mines, with workshops, storage houses, barracks and infrastructure in the central southern part of the island. The factory complex covered an area of 82 hectares, and the whole territory was surrounded by a double barbwire fence. According to memories, in 1954 the island hosted ca 30000 soldiers. This is most probably a very large exaggeration, but still characterises the extent of the complex.

In the years 1988-1994 approximately 13000 marine anti-ship mines were disarmed on the island. The quantity of military supplies still remaining on the island in 1992 was estimated to include 445 railway wagons. During the Cold War the mine factory on Naissaar was considered to be one of the most important military sites in Soviet Estonia. In the northern part of the island, a Zenith missile base was also situated. Of course, the whole island was closed to civilians [8].

At the same time, when looking at the Soviet military topographic maps, it can be seen that the whole island was made to look as if it was almost empty and covered in forest (Fig. 6.). Only the network of roads and railways arouses some suspicion: why would a small island with only a couple of villages need an elaborate road system and a railway? 
Today the anti-ship mine factory (Fig. 7.), workshops and the railway system are protected as cultural heritage, and the once forbidden layer of the Soviet landscape is open to the public and made visible once again.
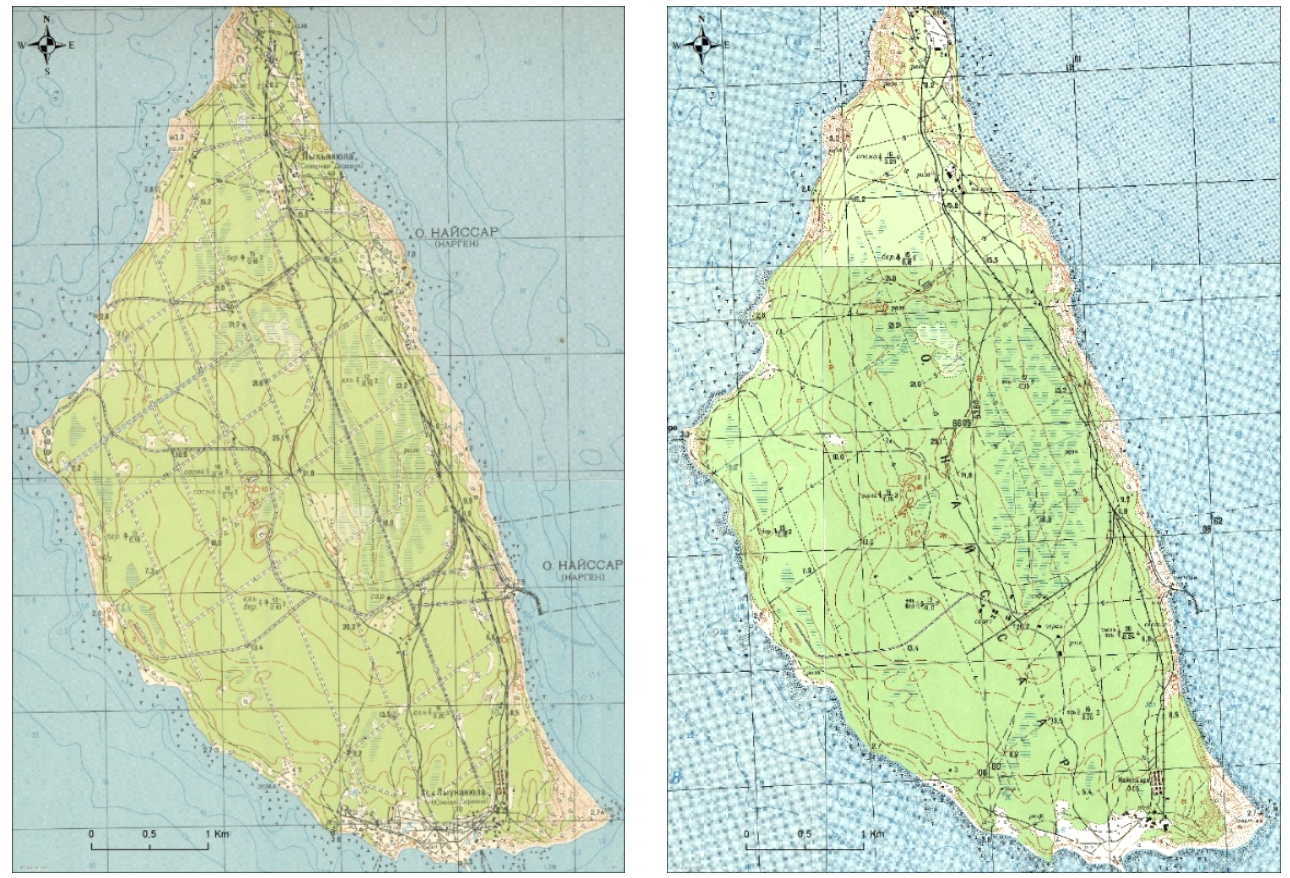

Fig. 6. The island of Naissaar in 1972 (c63-series) and 1987. An almost empty forested island with elaborate network of roads and railways hides an extensive anti-ship mine factory complex. These were drawn at 1: 25000 scale. (Source: Estonian Land Board).

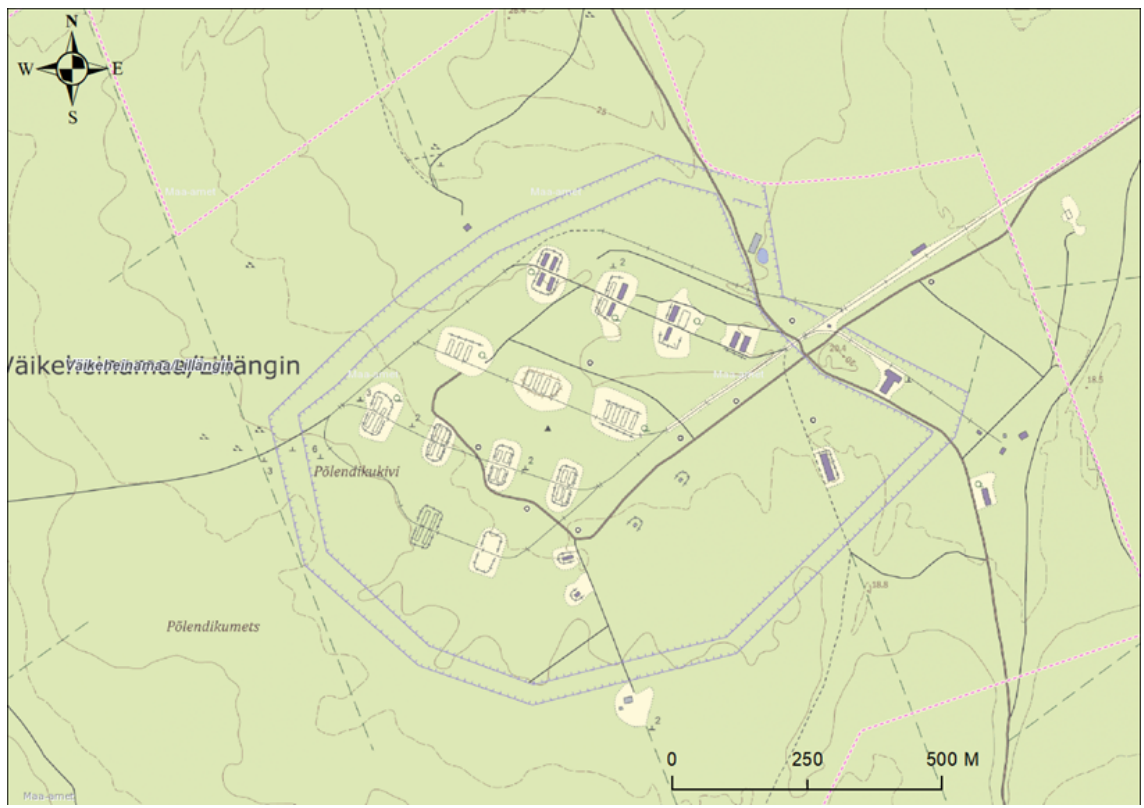

Figure 7. Remains of the Naisaare mine factory in 2017 (from a map produced at 1: 20000 scale). (Source: Estonian Land Board). 

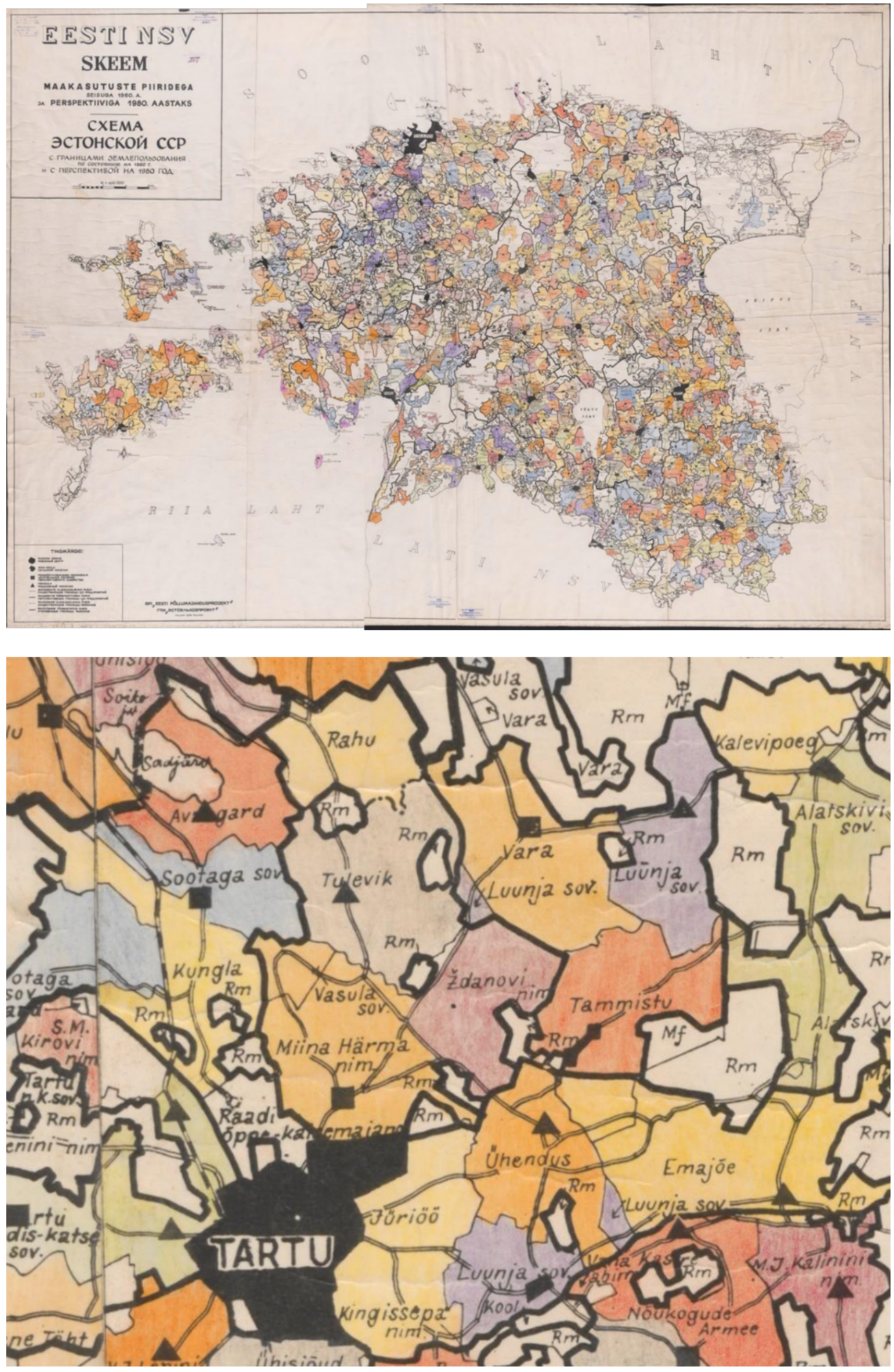

Fig. 8. a) The complete map of Estonia divided into kolkhoz or sovkhoz with a new pattern overlaid which is the future perspective; $\mathbf{b}$ ) is a detail, were the existing and proposed amalgamations can be seen more clearly. (Source: $\left[{ }^{2}\right]$ ). 


\section{Kolkhoz future mapping}

The maps of none military areas such as the collectivised rural landscape were not so secret - and according to the categories of maps it was possible to use ones of limited areas. Even here there were sometimes deliberate mistakes included such as inaccurate routes of electricity lines or switches place names - so that if maps were stolen and reproduced by enemies they could be traced. However, in general these maps did not lie so much, as practical uses were made from them for drainage and road constructions schemes.

Another way of lying can be understood as self-delusion - making claims which are not true yet believing in them, at least in public. This is in fact how the Soviet Union presented a system which was clearly inefficient by artificially inflating production numbers and so on. While it is the case that by the 1980s some kolkhoz and sovhoz had become quite efficient there was, even in the midst of the Brezhnev stagnation period and then the Gorbachov perestroika period a delusion that the system would continue to get better. So our final example is a map of the entire country which presents the total picture of the collectivisation status as at 1960 with a prognosis or future perspective on how it would look at $1980^{2}$. In it (Fig. 8.) it is possible to see how a number of existing kolkhoz and sovkhoz were expected to be amalgamated into much larger entities - presumably it was thought that bigger was always better

\section{Discussion and conclusions}

From this brief set of samples of maps created in the Soviet era we can obtain a glimpse of how difficult it was for the residents of Estonia to know their landscape, since no accurate maps at anything like a useful scale were allowed. People would only know their local area accurately from their own mental mapping as they lived there or from any maps they were able to use when carrying out kolkhoz development projects, for example.

We take maps for granted nowadays - and always did in Western countries. Today, with GoogleMaps and GoogleEarth as well as GPS navigation systems we can find out where we are and what lies around us extremely easily. It is difficult to imaging a situation when not only were maps unavailable but those that were presented a false picture of how the landscape actually was.

Information is power, and maps have always been closely associated with various forms of power as noted above. Thus, the people with no access to maps were disempowered and, as part of a propaganda initiative as well as an obsession with secrecy, the landscape shown to people through maps as well as controls over travel routes and other aspects was in very large part a false one. It was partly designed to show an idealised landscape in contrast with what was really happening.

\section{Acknowledgements}

MODSCAPES is a collaborative research project funded under the HERA - Humanities in the European Research Area 3rd Joint Research Programme dedicated to "Uses of the Past" (20162019). This project has received funding from the European Union's Horizon 2020 research and innovation programme under grant agreement $n^{\circ} 649307$. 


\section{Short resumes}

Martti Veldi MSc is an archaeologist and a Junior Researcher at the Estonian University of Life Sciences in Tartu, Estonia. He is also an inspector in the Estonian Heritage board responsible for identifying and protecting cultural heritage monuments.

Simon Bell PhD is Chair professor at the Estonian University of Life Sciences and Associate Director of the OPENspace Research Centre at the University of Edinburgh. He has been president of ECLAS, the European Council of Landscape Architecture Schools between 2012 and 2018.

\section{Bibliography}

1. MARDISTE, H. 2010. "Kõveraks väänatud Eesti. Pool sajandit meie maakaartide moonutamist ja salastamis" [Crooked Estonia. Half a century of deforming and classifying our maps], Akadeemia, $\mathrm{n}^{\circ}$ 7: 1182-1206. Retrieved from https://www.digar.ee/viewer/et/nlib-digar:104158/162425/page/20 [available on 14 January 2019].

2. VAREP, E. 1955. "L. A. Mellini Liivimaa atlas ning selle tähtsus Eesti NSV territooriumi uurimise ajaloos" [L. A. Mellin's Atalas of Livonia and its importance in the study of the territory of Soviet Estonia], Eesti NSV Teaduste Akadeemia Toimetised [Proceedings of the Academy of Sciences of the Estonian SSR], vol. 4, $\mathrm{n}^{\circ}$ 2: 300-316.

Retrieved from https://www.etera.ee/zoom/9531/view?page=318 [available on 14 January 2019].

3. NATIONAL ARCHIVES OF ESTONIA, 2019. Map Register. Web Site. Retrieved from: www.ra.ee/kaardid/ [available on 14 January 2019].

4. ESTONIAN LAND BOARD, 2019. Avalik WMS teenus [Public WMS-service]. Web page. Retrieved from: https://geoportaal.maaamet.ee/est/Teenused/AvalikWMS-teenus-p65.html [available on 14 January 2019].

5. HEADQUARTERS OF THE ESTONIAN DEFENCE FORCES, 2019. Air force. Web page. Retrieved from: http://www.mil.ee/en/air_force [available on 14 January 2019].

6. GUSTAVSON, H. 1993. Merekindlused Eestis 1913-1940 [Naval Strongholds in Estonia 1913-1940], Tallinn, Olion - Tallinna Raamatutrükikoda.

7. ÕUN, M. 2001. Eesti Merekindlused ja nende suurtükid 1918-1940 [Estonian Naval Strongholds and their Cannons 1918-1940], Tallinn, Tammiskilp Sõnasepp.

8. TÄHISTE, A \& MÕNISTE, M. 2017. Naissaare miinitöökoda. Muinsuskaitseline eksperdihinnang [Mine factory on Naissaar. Expert Assessment of Cultural Heritage], Archive of the National Heritage Board. 